\title{
THE IMPLEMENTATION OF SKIMMING TECHNIQUE TOWARDS STUDENTS' READING COMPREHENSION
}

\author{
Syaifudin Latif Darmawan \\ (English Department of Muhammadiyah University of Metro)
}

\begin{abstract}
The study is to find out whether skimming technique enhance students' reading comprehension at English Department of Muhammadiyah University of Metro, Academic Year 2015/2016. This research is conducted at English Study Program of Muhammadiyah University of Metro. The population of the research is the students of English department, while the sample of the research is the students at fourth semester of English department Muhammadiyah University of Metro. To determine the sample, the researcher employs purposive technique sampling. Then, To collect the data, the researcher used documentation, Observation, Interview and questionnaire. Furthermore, to analyze the data, the researcher apply some steps: (1) data reduction, (2) data display and (3) data conclusion. The result of research indicates that the skimming technique has significant contribution to students' reading comprehension at fourth semester of English Study Program, Muhammadiyah University of Metro.
\end{abstract}

\section{Keyword: Skimming Technique}

Language has an important role in the life of mankind. Without language, humans would have difficulty in communicating. With a language people can express their ideas, thoughts or ideas to other human beings. Beside that, in modern world, the language used in various fields including education, political, economic, social, cultural and others. In education, mastering foreign language is needed. With foreign languages, we can explore the world of education. As a result, the world of education in Indonesia country will get better and advanced, same with the world of education in developed countries. To be a developed country in the world of education, one thing that should be mastered namely English language. By mastering the English language, we can get a lot of benefits. For example in the field of education, we can access all the information we need regarding of education.

English has four skills: speaking, reading, listening and writing. In this research, the researcher will discuss one of english skills that is reading. Reading is a skill has an important role in in 
language learning. By having reading skill, the students will get any kinds of information. To get complete information, we need technique in reading. Therefore, in this research, the researcher propose the title "The Implementation of Skimming technique Towards Students' Reading Comprehension at English Study Program of Muhammadiyah University of Metro. The research is conducted to know whether skimming technique contribute to students' reading comprehension at sixth semester students of english study program, Muhammadiyah University of Metro.

\section{Formulation of the Problem}

Based on the bacground above, the reseacher can formulate the formulation of the problem as follows:

1. Does skimming technique contribute to students' reading comprehension at English study program of Muhammadiyah University of Metro?

\section{Reading Comprehension}

According to Nunan (1989:33) reading is viewed as a process of decoding written symbols, working from smaller units (individual letters) to larger ones (words, clauses and sentences). In other words, we use strategies to decode written forms in order to arrive at meaning. The other definition stated by Rumelhart in Aebersold and Field (1997: 5) reading involves the reader, the text, and the interaction between the reader and the text. In addition, Davies (1995: 1) says that reading is a private activity. It is a mental or cognitive process, which involves a reader in trying to follow and respond to a message from a writer, who is in distant space and time.

It means that, when the reader interacts with printed symbols, the reader decodes the written text. As the result, the messages are achieved. Therefore, reading is actually a sort of conversation between a writer and a reader. 
From those statements, it can be inferred that reading is a mental or cognitive process which involves the reader, the text, and the interaction between the reader and the text. Besides, in this process the reader decodes written symbols, it is begun from smaller units (individual letters) to larger ones (words, clauses and sentences) in order to get the meaning from the text.

Grellet (1998: 3) states that reading comprehension is understanding a written text or extracting the required information from it as efficiently as possible. In addition, White (1997: 22) states that comprehension involves recognizing the significance of the message, understanding the intentions of the writer, and going beyond what is written to guess at hidden, unstated or implied meaning. Moreover, Howel (1993: 182) writes that comprehension is the act combining information in passages with prior knowledge in order to construct meaning.

Another definition comes from Merisuo and Storm (2006) states that reading comprehension is a complex process: the reader constructs meaning by interacting with text using his or her previous knowledge and experience and the information that can be found in the text.

From the theories above, it can be concluded that reading comprehension is a complex process in which the reader interacts with the text and employs his/her previous knowledge, experience and information to extract the significant information/important information, understand the intentions of the writer, and goes beyond what is written to guess at hidden, unstated or implied meaning on the text.

\section{Teaching Reading}

In this discussion, the writer would like to explain about the stages of teaching reading and activities in each stage. Besides, the writer would also explain the kinds of reading assessment.

There are three stages in teaching reading they are pre-reading, during-reading and postreading. Each of these stages has its own characteristics, although they are related one to 
another. According to Celce and Muria (2001: 191). Pre-reading instruction can serve five important purposes. It helps students access background information, provides specific information, stimulates students interest, sets up students expectation and models strategic that students that students can later use on their own. Pre-reading instruction also involves some activities: previewing the text, skimming the text, answering questions about information in text, exploring key vocabulary and reflecting on or reviewing information from previously read texts in light of the topic of the new text.

Furthermore, during reading instruction, it guides students through the text, often focusing on understanding difficult concepts, making sense of complex sentences, considering relationship among ideas or character in the text and reading purposefully and strategically. In this stage, it involves some activities they are outlining or summarizing key ideas in a difficult section, Examining emotions and attitudes of key characters, determining sources of difficult and seeking clarification, looking for answers to questions posed during pre-reading activities, writing down prediction of what will come next.

Finally, post reading instruction typically extends ideas and information from the text while also ensuring that the major ideas and supporting information are well understood. In this stage, it involves some activities: completing a graphic organizers based on text information; expanding or changing a semantic map created earlier; listening to lecture and comparing information from the text and the lecture; ranking the importance in the text based on a set of sentences provided; answering question that demonstrate comprehension of the text.

\section{Skimming Technique}

Widiatmoko (2001: 19) states that a quick read is a blend of motor skills (eye movement) or visual capabilities with a person's cognitive abilities in reading. Skimming is a kind of reading that make our eyes move quickly viewed, pay attention to the written material to seek and obtain information (Tarin 2008: 33). Furthermore, according to the Admin (2012: 26) 
skimming is read quickly to find out the general contents or part of a reading. Based on some statements above, the researchers conclude that quick reading or skimming is a technique or strategy that functions assist students in finding important information in a text.

\section{Research Methodology}

\section{Setting of the research}

The research is conducted at English Study Program of Muhammadiyah University of Metro in Academic Year 2015/2016. English Study Program of UM Metro has qualified lecttures. Besides, it is suported by edequates fsascilities, one of them is English laboratory. It used as the place of toefl practice for the lecturers and students of english study program, Muhammadiyah University of Metro. In addition, this lab also as the the place of listening subject.

\section{Research Subject}

Research subject is the students of English Study Program of Muhammadiyah University of Metro Academic Year 2015/2016. Here, the whole students at English department of Muhammadiyah Univeristy of Metro: the students at second semester is 62 ; the students at fourth semester is 70 ; the students at sixth semester is 60 .

\section{Population}

The population is the total of all objects or individuals that have certain characteristics, clear and complete to be studied (Hasan, 2002: 58). Furthermore, according to Sugiyono (2010: 117) population is generalization region consisting of: objects / subjects that have certain qualities and characteristics defined by the researchers to learn and then drawn conclusions. Based on the opinion above, it can be concluded that the entire population is the subject of research. The population in this study is all students of English Study Program, Metro Muhammadiyah University Academic Year 2015/2016.

\section{Sample}


According Sugiyono (2010: 118) sample is part of the number and characteristics possessed by the population. In line with Sugiyono, hasan said samples are part of the population that is taken through the particular ways that also has a certain characteristic, clear and complete that is considered to represent the population (2002: 58). Based on the theories above, the sample can be concluded that the part of the population which is considered to represent the population. The sample in this study is the fourth semester students of English Study Program Muhammadiyah University Metro, Academic Year 2015/2016.

\section{Sampling Technique}

In this study, researchers employ a purposive sampling technique. According to Sugiono (2010: 124) using purposive sampling is sampling technique with a certain considerations. Furthermore, in this study, the researcher chose students at fourth and sixt semester of English department, University of Mummadiyah Metro, because they are familiar with using skimming techniques in reading subject.

\section{Technique Collecting Data}

In this study, there are several steps to get the data from beginning to end during the learning process. Researcher conducted observation, interviews and documentation.

\section{Data analysis technique}

In this study, researchers analyze the data using qualitative descriptive. Here are some steps to analyze the data:

1. Data Reduction (Data Reduction)

Reducing the data is to summarize, pick things that are basic, focusing on things that are important, look for themes and patterns and discard unnecessary.

2. Data Display (Data Presentation) 
In qualitative research, the presentation of data can be done in the form of brief descriptions, charts, and relations between categories, flowchart and the like. The most often used in presenting the data in qualitative research is the narrative text.

\section{Data Conclusion}

Preliminary conclusion expressed still provisional, and will change if no strong evidence supporting the next phase of the collection of the data.

\section{Discussion}

In this research, the researcher used four collecting data techniques they are observation, interviews, questionnaires and documentation. The expalanation are as follows:

1. Observation

The researcher observes the students at fourth semester during reading subject. The result of obsevation showed that the majority of fourth semester students of English study programs understand well about using skimming technique. The students believe that the techniques are contributed in raeding subject.

2. Interview

The researcher invited ten students at fourth semester of englsih study program tobe interviewed. The result of interviews indicated that ten students like reading subject. Besides, the students are also familiar with skimming technique.

3. Documentation

The researcher investigated the result of reading test fourth semester students of English Study Program. The result showed that many students got good scores, while only a few students got bad scores. It indicated that most of the students were familiar with the techniques and were able to use the techniques well in reading subject. 
Based on the data above, the researcher can conclude that skimming technique has significant contribution to the students at fourth sememster of English Study Program, Muhammadiyah Uniiversity of Metro. The three collecting data techniques showed that the students know well about using skimming technique in reading class. Besides, the students' vocabularies increased during the process of conducting the research. So, the students' score in reading comprehension are raised.

\section{Conlusion}

In this research, skimming technique has great impact in reading comprehension at fourth semester of english study program, Muhammadiyah University of Metro. The impact are as follow: First, skimming technique has assisted the students to get the gist of information in a paragraph or a text. Second, to increase students' reading comprehension more sifnificant, the lectures are suggested to train the students in using skiming technique in reading class. Then, the lecturers should give sort of texts in reading class. Finally, the lecturers always evaluate students' understanding by giving the test.

\section{Bibliography}

Aebersold, J.A and Field, M.L (1997). From Reader to Reading Teacher. New York: Cambridge University Press.

Admin. (2012). Teknik Membaca Cepat Skimming dan Scanning. Jakarta: Atmajaya

Arikunto, S. (2009). Prosedur Penelitian Suatu Pendekatan Praktek Edisi Revisi IV. Jakarta: PT Rineka Cipta

Burns, Paul C et.al (1984). Teaching Reading in Todays Elementary School. Boston: Houghton Mifflin Company.

Grellet, Francois. (1998). Developing Reading Skills. United Kingdom: Cambridge University Press. 
White, RV. (1997), The English Teacher's Handbook. England: Thomson Nelson and Sons Ltd.

Hasan, M. I. (2002). Pokok-Pokok Metodologi Penelitian dan Aplikasinya. Jakarta: Ghalia Indonesia.

Howel, Fot.et.al. (1993). Curriculum Based Evaluation 2nd Edition. California: Cole Publishing Company.

Jones, Darolyn (2004), Painless Reading Comprehension, New York: Barrons' Educational Series, Inc.

Merisuo-Storm, Tuula. (2006). Primary School Students' Reading Comprehension Skill.

Nunan, David. (1989). Designing Task for Communication Classroom. United Kingdom: Cambrigde University Press.

Nutall, Cristine, (1996), Teaching Reading Skiills in a foreign Language. Heinemann: Heinemann English Language Teaching.

Rahim, Farida. (2008) Pengajaran Membaca di Sekolah Dasar, Jakarta: Bumi Aksara

Sugiyono, (2010), Metode Penelitian Pendidikan (Pendekatan Kuantitatif, Kualitatif dan $R \& D)$. Bandung: CV Alfabeta.

Sous, David A. (2005). How the Britain Learns to Read. London: Corwin Press.

Soedarso. (2004). Speed Reading. Jakarta: Gramedia Pustaka Utama

Tarigan, Henry Guntur. 2008. Membaca Sebagai Suatu Keterampilan Berbahasa. Bandung: Angkasa.

Tomkins, Gail E and and Hoskisson Kenneth. (2004) Language Arts: Content and Teaching Strategies. New York. Macmillan Publishing Company.

eir, Cyril. J. (1998). Communicative Language Testing. Great Britain: Prentice Hall

Widiatmoko, Irwan. (2001). Super Speed Reading. Jakarta; Kompas Gramedia.

Zwiers, Jeff. (2004). Building Reading Comprehension Habits in Grades 6-12: A Toolkit of Classroom Activities. California: International Reading Association, Inc. 
Premise Journal Vo. 5 No.2 October 2016, ISSN online: 2442-482x ISSN printed:2089-3345 